\title{
Prevention of siderophore- mediated gut-derived sepsis due to $P$. aeruginosa can be achieved without iron provision by maintaining local phosphate abundance: role of $\mathrm{pH}$
}

Kathleen Romanowski ${ }^{1}$, Alexander Zaborin ${ }^{1}$, Hoylan Fernandez ${ }^{1,3}$, Valeriy Poroyko ${ }^{1}$, Vesta Valuckaite', Svetlana Gerdes ${ }^{2}$, Donald C Liu', Olga Y Zaborina ${ }^{1 *+}$ and John C Alverdy ${ }^{1 *+}$

\begin{abstract}
Background: During extreme physiological stress, the intestinal tract can be transformed into a harsh environment characterized by regio- spatial alterations in oxygen, $\mathrm{pH}$, and phosphate concentration. When the human intestine is exposed to extreme medical interventions, the normal flora becomes replaced by pathogenic species whose virulence can be triggered by various physico-chemical cues leading to lethal sepsis. We previously demonstrated that phosphate depletion develops in the mouse intestine following surgical injury and triggers intestinal $P$. aeruginosa to express a lethal phenotype that can be prevented by oral phosphate ([Pi]) supplementation.
\end{abstract}

Results: In this study we examined the role of pH in the protective effect of [Pi] supplementation as it has been shown to be increased in the distal gut following surgical injury. Surgically injured mice drinking $25 \mathrm{mM}$ [Pi] at $\mathrm{pH} 7.5$ and intestinally inoculated with $P$. aeruginosa had increased mortality compared to mice drinking $25 \mathrm{mM}$ $[\mathrm{Pi}]$ at $\mathrm{pH} 6.0(\mathrm{p}<0.05)$. This finding was confirmed in C. elegans. Transcriptional analysis of $P$. aeruginosa demonstrated enhanced expression of various genes involved in media alkalization at pH 6.0 and a global increase in the expression of all iron-related genes at $\mathrm{pH}$ 7.5. Maintaining the $\mathrm{pH}$ at 6.0 via phosphate supplementation led to significant attenuation of iron-related genes as demonstrated by microarray and confirmed by QRT-PCR analyses.

Conclusion: Taken together, these data demonstrate that increase in $\mathrm{pH}$ in distal intestine of physiologically stressed host colonized by $P$. aeruginosa can lead to the expression of siderophore-related virulence in bacteria that can be prevented without providing iron by maintaining local phosphate abundance at pH 6.0. This finding is particularly important as provision of exogenous iron has been shown to have untoward effects when administered to critically ill and septic patients. Given that phosphate, $\mathrm{pH}$, and iron are near universal cues that dictate the virulence status of a broad range of microorganisms relevant to serious gut origin infection and sepsis in critically ill patients, the maintenance of phosphate and $\mathrm{pH}$ at appropriate physiologic levels to prevent virulence activation in a site specific manner can be considered as a novel anti-infective therapy in at risk patients.

\footnotetext{
* Correspondence: ozaborin@surgery.bsd.uchicago.edu; jalverdy@surgery.bsd. uchicago.edu

† Contributed equally

'Department of Surgery, the University of Chicago, 5841 S. Maryland,

Chicago, IL 60637, USA

Full list of author information is available at the end of the article
} 


\section{Background}

Pseudomonas aeruginosa is an opportunistic pathogen that is prevalent in the gut of hospitalized patients exposed to antibiotics and extreme physiologic stress such as major organ transplantation, injury, and sudden and severe insults [1-3]. P. aeruginosa is one of the most common causes of severe sepsis and its primary site of colonization and source of subsequent infection is the intestinal tract reservoir [3-5]. In previous work from our laboratory we analyzed multi-drug resistant isolates of Pseudomonas aeruginosa obtained from critically ill patients for their ability to disrupt the intestinal epithelial barrier and cause lethal gut-derived sepsis [6]. In these studies we identified that certain highly virulent and lethal isolates of $P$. aeruginosa respond to phosphate limitation by expressing outer surface appendages containing the phosphate signaling protein PstS [7]. We hypothesized that such responsiveness of these strains to phosphate limitation might have evolved from exposure to the depleted phosphate conditions present in a physiologically stressed host. We previously measured phosphate concentration in the intestine of mice following surgical injury and discovered that phosphate becomes rapidly depleted in the distal intestinal tract mucosa (cecum) and is associated with enhanced PstS expression in $P$. aeruginosa colonizing the mouse gut [8]. Further work using the prototype strain PAO1 demonstrated in both C. elegans and mice, that phosphate limitation causes activation of a lethal phenotype in $P$. aeruginosa that can be attenuated when local phosphate abundance/sufficiency is created via oral supplementation $[9,10]$. Molecular analysis of this response demonstrated that phosphate limitation activates a lethal phenotype in PAO1 via signaling mechanisms interconnecting phosphate acquisition systems (PstS-PhoB), quorum sensing (MvfR-PQS), and iron acquisition system (pyoverdin). We therefore hypothesized that maintenance of phosphate abundance/sufficiency at sites of $P$. aeruginosa colonization, such as the distal gut, may be a potential strategy to prevent virulence activation and hence mortality through the course of extreme physiologic stress when local phosphate stores become depleted.

Yet another important local microenvironmental cue that might affect the virulence and lethality of strains of $P$. aeruginosa that colonize the gut is $\mathrm{pH}$. Measurements of luminal $\mathrm{pH}$ in the normal gastrointestinal tract have shown a progressive increase in $\mathrm{pH}$ from the duodenum to the terminal ileum, a decrease in the cecum, and then a slow rise along the colon to the rectum [11]. The relatively acidic $\mathrm{pH}$ range of 5.8-6.7 in the human proximal colon (cecum, right colon), the principle site of microbial colonization, has been repeatedly reported using various methods of $\mathrm{pH}$ analysis [12-15]. Importantly, $\mathrm{pH}$ has been found to be markedly increased in the proximal colon after severe insults such as sepsis, trauma, shock, and inflammatory bowel disease in human $[1,11]$ as well as in mouse models of physiological stress induced by major surgery [16]. Yet whether changes in luminal $\mathrm{pH}$ correspond to changes within the colon mucosa, the primary site of a colonization and invasion of $P$. aeruginosa is unknown. As changes in $\mathrm{pH}$ in the proximal colon mucosa have the potential to affect the valence state and hence availability of both phosphate and iron to $P$. aeruginosa during intestinal colonization, the aims of the present study were to examine if $\mathrm{pH}$ changes in the proximal colon mucosa develop in mice following surgical injury that affect the ability of oral phosphate supplementation to protect against lethal sepsis due to intestinal $P$. aeruginosa.

\section{Methods}

\section{Bacterial strains}

Studies were performed with $P$. aeruginosa PAO1 strains obtained from two laboratories, MPAO1 (B. Iglewski, the original strain used to create the transposon mutant library at the University of Washington), and CorPAO1 (P. Cornelis), as well as with the CorPAO1 derivative mutant $\Delta \mathrm{PvdD} / \Delta \mathrm{PchEF}$.

\section{Mouse model of lethal gut-derived sepsis}

Animal experiments were approved by the Animal Care and Use Committee at the University of Chicago (IACUC protocol 71744). Male C57BL6/HSD mice weighing 18 to $22 \mathrm{~g}$ were used for all experiments. Gutderived sepsis was modeled by performing a $30 \%$ surgical left lateral hepatectomy with simultaneous injection of $10^{7}$ CFU P. aeruginosa into cecum of mice pre-fasted 18 hours prior to surgery as previously described [16]. Mice were allowed access to either tap water, or $25 \mathrm{mM}$ potassium phosphate-buffer (PB) $\mathrm{pH} 7.5$, or $25 \mathrm{mM} \mathrm{PB}$ $\mathrm{pH} 6.0$ through over the course of the experimental period.

\section{Measurement of intestinal mucosal $\mathrm{pH}$}

Intestinal mucosa (overlying mucus and intestinal epithelial cells) $\mathrm{pH}$ was measured with phenol red. Following $24 \mathrm{hrs}$ after surgery, mice were sacrificed, and distal intestine of mice was harvested from rectum to jejunum, gently washed with water to remove loose luminal contents and then stained by flashing 5 times with $0.4 \%$ phenol red in buffer $(0.145 \mathrm{M} \mathrm{NaCl}, 0.002$ $\left.\mathrm{M} \mathrm{KH}_{2} \mathrm{PO}_{4}, 0.003 \mathrm{M} \mathrm{Na}_{2} \mathrm{HPO}_{4}\right)$. The intestine was opened longitudinally and mucosal $\mathrm{pH}$ measured semiquantitatively using $\mathrm{pH}$ standards stained with phenol red. 


\section{C. elegans model}

C. elegans killing assays were performed as we previously reported [9] with modifications. Briefly, P. aeruginosa PAO1 grown on solid TSB was collected and suspended in either $25 \mathrm{mM}$ potassium phosphate buffer (PB), $\mathrm{pH} 6.0$ or $\mathrm{PB}$ pH 7.5 to a $30 \mu \mathrm{l}$ volume that was poured on NGM agarized media (peptone, $2.5 \mathrm{~g} / \mathrm{L}$; $\mathrm{NaCl}, 3 \mathrm{~g} / \mathrm{L} ; \mathrm{MgSO}_{4}, 1 \mathrm{mM}$; $\mathrm{CaCl}_{2}, 1 \mathrm{mM}$; agar $17 \mathrm{~g} / \mathrm{L}$ ) supplemented with $25 \mathrm{mM}$ PB pH 6.0 or $\mathrm{pH} 7.5$, respectively. PAO1 lawns were grown during $24 \mathrm{hrs}$ at $37^{\circ} \mathrm{C}$ following overnight incubation at room temperature, and then were used for feeding C. elegans. As a control of phosphate limitation, $P$. aeruginosa PAO1 lawns were prepared on NGM containing $0.1 \mathrm{mM} \mathrm{PB}$, pH6.0. Pre-fasted worms were transferred onto lawns and mortality followed for up to $60 \mathrm{hrs}$.

\section{Genome-wide transcriptional analysis}

All samples for gene expression analysis were prepared in triplicate. $P$. aeruginosa MPAO1 cells collected from lawns grown on $\mathrm{NGM} /[\mathrm{Pi}] 25 \mathrm{mM}, \mathrm{pH} 6.0$ or $\mathrm{NGM} /[\mathrm{Pi}]$ 25, pH 7.5 were used for RNA isolation as previously described. Microarray analysis was performed using Affymetrix $P$. aeruginosa GeneChips (Affymetrix, Santa Clara, CA) at the University of Chicago Functional Genomics Facility and data were analyzed as previously described [9]. Microarray data were deposited in GEO database, accession number GSE29789.

\section{QRT-PCR analysis}

Multiplex qRT-PCR was performed to simultaneously analyze the expression of selected genes in $P$. aeruginosa MPAO1 grown under $\mathrm{pH} 6.0$ and $\mathrm{pH} 7.5$ in NGM-Pi 25 $\mathrm{mM}$. Gene clusters for the analysis were chosen as representatives of phosphate signaling and acquisition, quorum sensing, and iron acquisition. Overnight $P$. aeruginosa MPAO1 culture was diluted 1:50 in triplicate in $25 \mathrm{mM}$ phosphate NGM media at $\mathrm{pH} 6.0$ and 7.5, and grown for $9 \mathrm{hrs}$ at $37^{\circ} \mathrm{C}$. RNA was isolated and reversed to cDNA as previously described [7]. QRT-PCR analysis was performed as previously described [9]. Briefly, gene specific primers $\left(\mathrm{Tm}=60^{\circ} \mathrm{C}\right)$ to amplify $100 \mathrm{bp}$ fragments of target mRNA were designed based on in silica analysis for amplification specificity by BLAST search against the database of $P$. aeruginosa PAO1 genome. Gene expression was normalized to tpiA (PA4748) whose expression was not influenced by $\mathrm{pH}$ in microarray analysis, and which was used in our previous QRTPCR analyses [9]. Fold changes of expression levels were determined by normalization to expression at $\mathrm{pH}$ 6.0.

\section{Pyoverdin assay}

Pyoverdin production was measured by fluorescence at $400 \pm 10 / 460 \pm 10$ excitation/emission, and measurements of relative fluorescence units (RFU) were normalized to cell density units as absorbance at 600 $\mathrm{nm}$ in bacterial cultures growing in black, clear bottom 96-well plates (Corning Incorporated, Corning, NY, Costar 3603) using a 96-well Microplate Fluorimeter Plate Reader (Synergy HT, Biotek Inc., Winooski, VT). In the experiments with iron supplementation, pyoverdin was measured in supernatants by absorbance at 405 $\mathrm{nm}$ as previously described [17], and normalized to initial cell density.

\section{Iron concentration assay}

Iron was measured using a Roche/Hitachi MOD P automated clinical chemistry analyzer using the FerroZine method (the minimum detection limit is $0.1 \mu \mathrm{g} / \mathrm{ml}$ ). Results were reproduced in 3 biological replicates.

\section{Bioinformatics}

Microarray data were analyzed using gene annotations provided by the SEED database http://www.theSEED. org/ and Pseudomonas Genome Database http://www. pseudomonas.com/.

\section{Statistical analysis}

Statistical analysis of the data was performed with Student t-test using Sigma plot software, and Kaplan-Maier survival graphs using SPSS 18 software.

\section{Results}

Surgical injury ( $30 \%$ hepatectomy) increases the distal intestinal mucosal $\mathrm{pH}$ that can be maintained by $\mathrm{pH}$ adjusted oral phosphate supplementation

In order to determine whether the $\mathrm{pH}$ of the intestinal mucosa, the major colonization site of microbial pathogens, is affected by surgical injury, mucosal $\mathrm{pH}$ was measured using phenol red staining of intestinal segments of control and surgically injured mice. The $\mathrm{pH}$ of proximal colon segments, the densest region of microbial adherence, was measured in mice 22 hours following sham laparotomy or $30 \%$ hepatectomy. Results demonstrated $\mathrm{pH}$ shift from $\sim 6.0$ in sham mice to $7.0-7.5$ in mice subjected to $30 \%$ hepatectomy (Figure 1A). In mice drinking an oral ad libitum solution of 25 $\mathrm{mM}$ phosphate buffer adjusted to $\mathrm{pH} 6.0$ or 7.5 , intestinal mucosal $\mathrm{pH}$ in the proximal colon stabilized to the corresponding $\mathrm{pH}$ suggesting that, in mice, distal intestinal $\mathrm{pH}$ can be manipulated by oral $\mathrm{pH}$ adjustment (Figure $1 B)$

\section{Oral phosphate protects against the lethal effect of intestinal $P$. aeruginosa following surgical injury in a $\mathrm{pH}$ dependent manner}

We next determined the effect of $\mathrm{pH}$ on the expression of a lethal phenotype in intestinal $P$. aeruginosa using a 


\section{$\begin{array}{llll}7.5 & 7.0 & 6.5 & 6.0\end{array}$

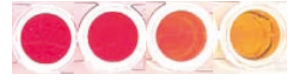

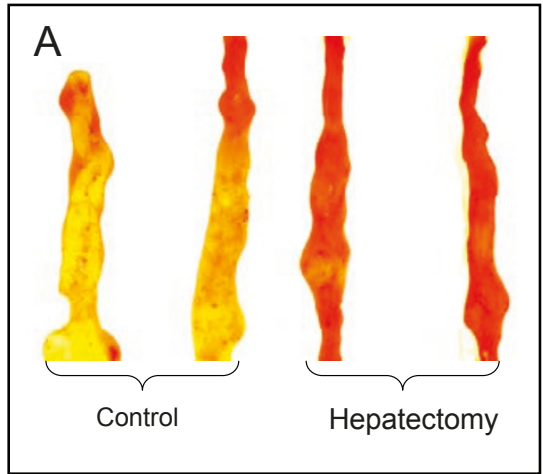

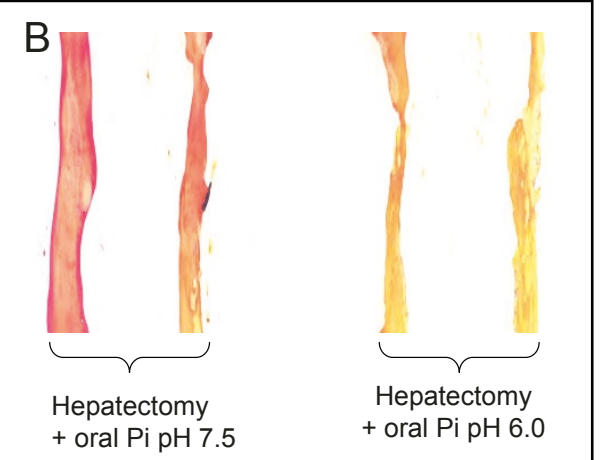

Figure 1 Intestinal mucus pH. Red phenol staining of (A) proximal colon of control and surgically stressed mice (30\% hepatectomy), and (B) proximal colon of surgically stressed mice drinking $25 \mathrm{mM}$ phosphate solution at $\mathrm{pH} 7.5 \mathrm{or} \mathrm{pH} 6.0$. Experiments were performed in triplicate and representative images of the colon isolated and stained with $0.04 \%$ phenol red from 2 mice of each group are shown.

model developed by our laboratory $[16,18]$. In this model, mice are subjected to an otherwise fully recoverable surgical injury ( $30 \%$ hepatectomy) with simultaneous injection of $P$. aeruginosa into the cecum which consistently results in $>60 \%$ mortality in $48 \mathrm{hr}$. In the present study, to generate negative controls, groups of mice were subjected to hepatectomy without injection of $P$. aeruginosa and drank either water, or $25 \mathrm{mM}$ [Pi], $\mathrm{pH} 6.0$, or $25 \mathrm{mM}$ [Pi], pH 7.5 ad libitum $(\mathrm{n}=16 /$ group). No mice in any of these groups developed signs of sepsis or mortality at 48 hours and appeared completely healthy. In contrast, and consistent with our previous studies in this model [7-9], mice drinking water ad libitum and intestinally inoculated with $P$. aeruginosa PAO1 following surgical hepatectomy developed gross signs of sepsis (chromodacctyrrhea, ruffled fur, lethary, scant diarrhea) and a $\sim 60 \%$ mortality rate at 48 hours. Mortality in mice intestinally inoculated with $P$. aeruginosa PAO1 following 30\% hepatectomy and drinking 25 $\mathrm{mM}[\mathrm{Pi}], \mathrm{pH} 7.5$ ad libitum was significantly attenuated (from $60 \%$ to $30 \%$ ) with an even further mortality attenuation down to $~ 10 \%$ when mice drank $25 \mathrm{mM}$ [Pi], pH 6.0 (Figure 2A).

In order to define the effect of $\mathrm{pH}$ on the lethality of $P$. aeruginosa, we used a more ordered host model system of $C$. elegans where worms feed on $P$. aeruginosa lawns grown at varying levels of phosphate and $\mathrm{pH}$. Briefly, nematodes fed on $P$. aeruginosa lawns grown on agarized Nematode Growth Media (NGM) in which $25 \mathrm{mM}$ potassium-phosphate buffer was adjusted to $\mathrm{pH} 6.0$ or $\mathrm{pH}$ 7.5. Suspension of P. aeruginosa PAO1 to create the bacterial lawns was also prepared in 25 $\mathrm{mM}[\mathrm{Pi}]$ at $\mathrm{pH} 6.0$ or 7.5 respectively to maintain consistency throughout the experimental period. As positive controls, parallel experiments were performed where worms fed on lawns of $P$. aeruginosa grown on low phosphate medium $(0.1 \mathrm{mM})$ similar to our previously published experiments [9]. Results demonstrated that the killing effect of $P$. aeruginosa against C. elegans at high phosphate concentration was enhanced at pH 7.5 compared to 6.0 (Figure 2B). Importantly, low phosphate conditions induced the highest lethality rate consistent with our previous findings and demonstrated that extracellular phosphate is a major cue that activates virulence [9]. Previous work from our laboratory demonstrated that red material accumulated in the digestive tube of dying of C. elegans worms feeding on $P$. aeruginosa at low phosphate that consisted of the $P$. aeruginosa virulence-related quinolone signal $\mathrm{PQS}$ complexed with iron (PQS-Fe ${ }^{3}$ $\left.{ }^{+}\right)$. This complex was determined to be toxic to C. elegans especially when combined with rhamnolipids [9]. In the current study, the red material was not observed when $C$. elegans fed on $P$. aeruginosa PAO1 lawns grown at [Pi] $25 \mathrm{mM}, \mathrm{pH} 7.5$ suggesting a lack of either PQS or pyoverdin production. The observation of yellow-green coloration suggested however that pyoverdin was produced at $[\mathrm{Pi}] 25 \mathrm{mM} \mathrm{pH} \mathrm{7.5}$. It is important to note that the adjustment of $\mathrm{pH}$ did not affect the intense green coloration under low phosphate conditions suggesting that phosphate limitation is still a major factor for green pigment production (Figure 2C). Furthermore, enhanced pyoverdin production under conditions of phosphate limitation was not affected if $\mathrm{pH}$ is stabilized using $25 \mathrm{mM}$ HEPES, pH7.5 or $25 \mathrm{mM}$ MOPS, pH 6.0 (Figure 2D). 
A
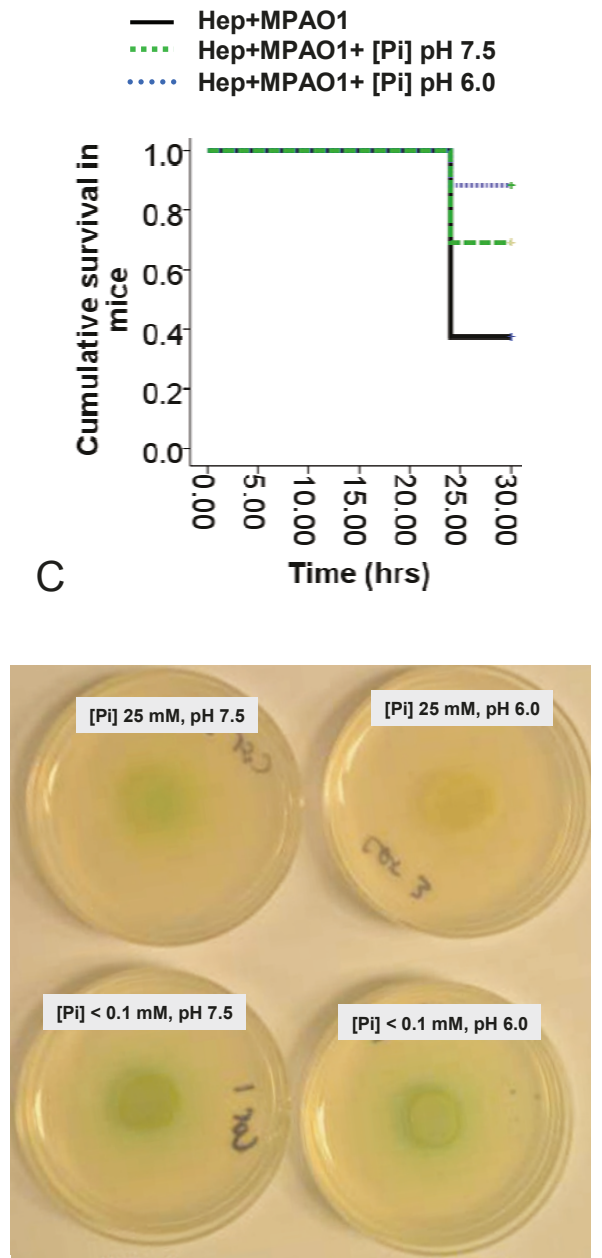

B

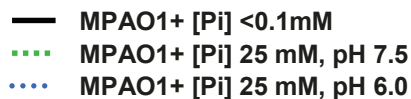

.... MPAO1+[Pi] $25 \mathrm{mM}, \mathrm{pH} 6.0$
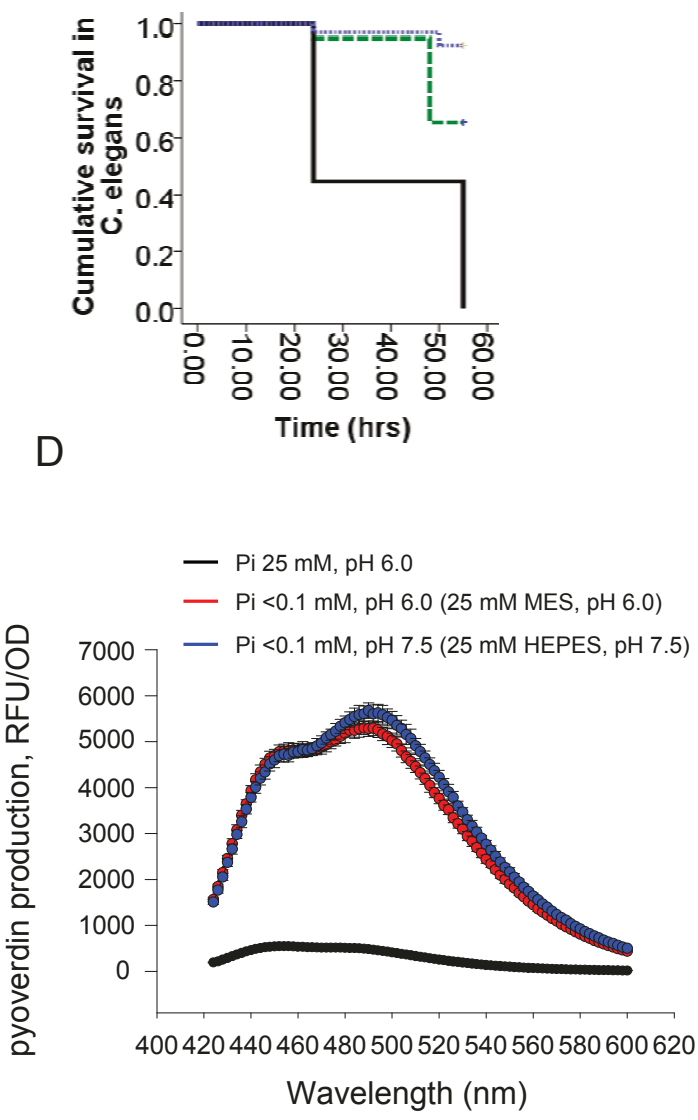

Figure 2 Effect of $\mathrm{pH}$ on P. aeruginosa PAO1 virulence and pyoverdin production. (A) Survival in mice subjected to hepatectomy and intestinal injection of $P$. aeruginosa. All mice were drank either water (var. Hep+MPAO1), 25 mM potassium phosphate buffer at pH 6.0 (var. Hep $+\mathrm{MPAO} 1+[\mathrm{Pi}] \mathrm{pH}$ 6.0), or $25 \mathrm{mM}$ potassium phosphate buffer at pH 7.5 (var. Hep+MPAO1+[Pi] pH 7.5). Results were reproduced in 3 experiments, $n=16 /$ group, $\mathrm{p}<0.05$ in between pH7.5 and pH6.0 groups. (B) Survival in C. elegans feeding on P. aeruginosa PAO1 lawns. Results were reproduced in triplicate, $n=63$ /group, $\mathrm{p}<0.05$ in between $\mathrm{pH7.5}$ and pH6.0 groups. (C) Pigmentation of $P$. aeruginosa PAO1 lawns grown at different phosphate and pH levels. The pH shift from 6.0 to 7.5 changes pigmentation on lawns containing Pi 25 mM. However, highly intense pigmentation is observed in P. aeruginosa PAO1 when grown as lawns at low $(<0.1 \mathrm{mM})$ phosphate independent of pH. (D) The enhanced production of pyoverdin under conditions of phosphate limitation is not affected by $\mathrm{pH}$ changes.

A pH of 7.5 at high phosphate concentration $(25 \mathrm{mM})$ induces the expression of iron starvation (IS) and ferrous uptake regulated (FUR) genes but not MvfR-PQS and results in expression of siderophore-mediated virulence in $P$. aeruginosa

We next performed a genome wide transcriptome analysis of PAO1 grown as lawns on NGM at $\mathrm{pH} 7.5$ versus pH 6.0 (deposited in GEO database, accession number GSE29789) to more completely understand the virulence profile associated with $P$. aeruginosa lethality in the $C$. elegans model. Results demonstrated that a $\mathrm{pH}$ shift from 6.0 to 7.5 under conditions of phosphate abundance $(25 \mathrm{mM})$ led to increased expression of all iron- dependent genes in $P$. aeruginosa PAO1 (Table 1). A significant (1.5-10.9 fold) increase in the expression of FUR regulated genes was observed suggesting that $P$. aeruginosa experiences intracellular iron insufficiency, perhaps owing to a relative decrease in iron solubility at a more alkaline $\mathrm{pH}$. Among FUR regulated genes of interest was $p v d S$ (PA2426) which encodes the sigma factor PvdS, a transcriptional regulator that controls the expression of the IS regulon including genes involved in the non-ribosomal biosynthesis of the siderophore pyoverdin, and the lethal toxin exotoxin $\mathrm{A}(\operatorname{tox} A)$. Data demonstrated that $p v d S$ itself as well as components of the PvdS-regulated iron siderophore sensor and receptor 
Table $1 P$. aeruginosa genes with enhanced expression at pH 7.5 vs pH 6.0

\begin{tabular}{|c|c|c|c|c|c|}
\hline PA ID & $\begin{array}{l}\text { Gene } \\
\text { name }\end{array}$ & $\begin{array}{l}\text { Fold expression } \\
\text { pH7.5 vs pH6.0 }\end{array}$ & Regulon & Function & Subsystem \\
\hline PA1134 & & 2.58 & IS & probable membrane protein & \\
\hline PA1148 & toxA & 2.33 & IS & exotoxin A precursor & \\
\hline PA2384 & & 4.78 & & $\begin{array}{l}\text { Hypothetical protein in pyoverdin gene cluster/Fe2 } \\
+/ Z n 2+\text { uptake regulation proteins }\end{array}$ & Siderophore_Pyoverdine \\
\hline PA2385 & pvdQ & 2.56 & FUR & $\begin{array}{l}\text { Acyl-homoserine lactone acylase PvdQ (EC 3.5.1.-), } \\
\text { quorum-quenching }\end{array}$ & Siderophore_Pyoverdine \\
\hline PA2386 & pvdA & 2.99 & IS & $\begin{array}{l}\text { L-ornithine 5-monooxygenase (EC 1.13.12.-), PvdA of } \\
\text { pyoverdin biosynthesis }\end{array}$ & Siderophore_Pyoverdine \\
\hline PA2389 & pvdR & 2.36 & IS & pyoverdine-specific efflux macA-like protein & Siderophore_Pyoverdine \\
\hline PA2390 & pvdT & 2.01 & IS & Pyoverdine efflux carrier and ATP binding protein & Siderophore_Pyoverdine \\
\hline PA2391 & opmQ & 1.86 & is & Outer membrane pyoverdine eflux protein & Siderophore_Pyoverdine \\
\hline PA2392 & pvdP & 2.98 & IS & $\begin{array}{l}\text { Pyoverdine biosynthesis related protein PvdP, Twin- } \\
\text { arginine translocation pathway signal domain }\end{array}$ & Siderophore_Pyoverdine \\
\hline PA2393 & pvdM & 3.43 & IS & Putative dipeptidase, pyoverdin biosynthesis PvdM & Siderophore_Pyoverdine \\
\hline PA2394 & $\mathrm{pvdN}$ & 3.24 & IS & $\begin{array}{l}\text { Pyoverdin biosynthesis protein PvdN, putative } \\
\text { aminotransferase, class } V\end{array}$ & Siderophore_Pyoverdine \\
\hline PA2395 & pvdO & 2.00 & IS & PvdO, pyoverdine responsive serine/threonine kinase & Siderophore_Pyoverdine \\
\hline PA2396 & $\mathrm{pvdF}$ & 2.53 & IS & $\begin{array}{l}\text { Pyoverdine synthetase PvdF, N5-hydroxyornithine } \\
\text { formyltransferase }\end{array}$ & Siderophore_Pyoverdine \\
\hline PA2397 & pvdE & 3.16 & IS & $\begin{array}{l}\text { PvdE, pyoverdine ABC export system, fused ATPase } \\
\text { and permease components }\end{array}$ & Siderophore_Pyoverdine \\
\hline PA2398 & fpvA & 4.07 & IS & $\begin{array}{l}\text { Outer membrane ferripyoverdine receptor FpvA, } \\
\text { TonB-dependent }\end{array}$ & Siderophore_Pyoverdine \\
\hline PA2399 & pvdD & 3.62 & IS & $\begin{array}{l}\text { Pyoverdine sidechain non-ribosomal peptide } \\
\text { synthetase PvdD }\end{array}$ & Siderophore_Pyoverdine \\
\hline PA2400 & pvdJ & 3.84 & IS & $\begin{array}{l}\text { Pyoverdine sidechain non-ribosomal peptide } \\
\text { synthetase PvdJ }\end{array}$ & Siderophore_Pyoverdine \\
\hline PA2402 & pvdl & 4.22 & IS & $\begin{array}{l}\text { Pyoverdine sidechain non-ribosomal peptide } \\
\text { synthetase Pvdl }\end{array}$ & Siderophore_Pyoverdine \\
\hline PA2403 & & 4.62 & & Putative iron-regulated membrane protein & Siderophore_Pyoverdine \\
\hline PA2404 & & 4.96 & & Putative thiamine pyrophosphate-requiring enzyme & Siderophore_Pyoverdine \\
\hline PA2405 & & 5.71 & & Hypothetical protein in pyoverdin gene cluster & Siderophore_Pyoverdine \\
\hline PA2406 & & 3.84 & & Hypothetical protein in pyoverdin gene cluster & Siderophore_Pyoverdine \\
\hline PA2407 & & 2.34 & & $\begin{array}{l}\text { Cation ABC transporter, periplasmic cation-binding } \\
\text { protein, PA2407 homolog }\end{array}$ & Siderophore_Pyoverdine \\
\hline PA2408 & & 2.82 & & $\begin{array}{l}\text { ABC transporter in pyoverdin gene cluster, ATP- } \\
\text { binding component }\end{array}$ & Siderophore_Pyoverdine \\
\hline PA2409 & & 1.69 & & $\begin{array}{l}\text { ABC transporter in pyoverdin gene cluster, permease } \\
\text { component }\end{array}$ & Siderophore_Pyoverdine \\
\hline PA2410 & & 1.84 & & $\begin{array}{l}\text { ABC transporter in pyoverdin gene cluster, } \\
\text { periplasmic component }\end{array}$ & Siderophore_Pyoverdine \\
\hline PA2411 & & 2.98 & IS & $\begin{array}{l}\text { Probable thioesterase involved in non-ribosomal } \\
\text { peptide biosynthesis, PA2411 homolog }\end{array}$ & Siderophore_Pyoverdine \\
\hline PA2412 & & 3.12 & IS & Hypothetical MbtH-like protein & Siderophore_Pyoverdine \\
\hline$\overline{P A 2413}$ & $\mathrm{pvdH}$ & 3.04 & IS & $\begin{array}{l}\text { Pyoverdin biosynthesis protein } \mathrm{PvdH}, \mathrm{L}-2,4- \\
\text { diaminobutyrate:2-oxoglutarate aminotransferase }\end{array}$ & Siderophore_Pyoverdine \\
\hline PA2424 & pvdL & 3.20 & IS & Pyoverdine chromophore precursor synthetase PvdL & Siderophore_Pyoverdine \\
\hline PA2425 & pvdG & 4.07 & IS & $\begin{array}{l}\text { Thioesterase PvdG involved in non-ribosomal } \\
\text { peptide biosynthesis }\end{array}$ & Siderophore_Pyoverdine \\
\hline PA2426 & pvdS & 5.21 & FUR & Sigma factor PvdS, controling pyoverdin biosynthesis & Siderophore_Pyoverdine \\
\hline PA2427 & & 6.13 & is & Hypothetical protein PvdY & Siderophore_Pyoverdine \\
\hline
\end{tabular}


Table $1 P$. aeruginosa genes with enhanced expression at pH 7.5 vs pH 6.0 (Continued)

\begin{tabular}{|c|c|c|c|c|c|}
\hline PA4168 & $f p v B$ & 2.03 & & $\begin{array}{l}\text { Outer membrane ferripyoverdine receptor FpvB, for } \\
\text { Type I pyoverdine }\end{array}$ & Siderophore_Pyoverdine \\
\hline PA5150 & & 2.44 & IS & probable short-chain dehydrogenase & \\
\hline PA0471 & fluR & 2.75 & FUR & probable transmembrane sensor & \\
\hline PA0472 & flul & 2.59 & FUR & probable sigma-70 factor, ECF subfamily & \\
\hline PA0672 & hemO & 3.61 & FUR & $\begin{array}{l}\text { Heme oxygenase HemO, associated with heme } \\
\text { uptake }\end{array}$ & Hemin_transport_system \\
\hline PA2467 & foxR & 2.08 & FUR & Fe2+-dicitrate sensor, membrane component & \\
\hline PA2468 & foxl & 2.86 & FUR & probable sigma-70 factor, ECF subfamily & \\
\hline PA4227 & pchR & 4.73 & FUR & Transcriptional regulator PchR & Siderophore_pyochelin \\
\hline PA4467 & & 7.46 & FUR & Metal transporter, ZIP family & \\
\hline PA4468 & sodM & 5.59 & FUR & Manganese superoxide dismutase (EC 1.15.1.1) & \\
\hline PA4469 & & 10.90 & FUR & FOG: TPR repeat & \\
\hline PA4470 & fumC1 & 7.91 & FUR & Fumarate hydratase class II (EC 4.2.1.2) & TCA_Cycle \\
\hline PA4471 & & 7.01 & FUR & FagA protein & \\
\hline PA4515 & & 2.80 & FUR & Iron-uptake factor PiuC & Transport_of_Iron \\
\hline PA4516 & & 1.87 & FUR & FOG: TPR repeat, SEL1 subfamily & \\
\hline PA4708 & phuT & 2.00 & FUR & Heme-transport protein, PhuT & Hemin_transport_system \\
\hline PA4709 & & 2.22 & FUR & probable hemin degrading factor & Hemin_transport_system \\
\hline PA4710 & phuR & 2.00 & FUR & $\begin{array}{l}\text { Haem/Haemoglobin uptake outer membrane } \\
\text { receptor PhuR precursor }\end{array}$ & Ton_and_Tol_transport_systems \\
\hline PA4895 & & 1.47 & FUR & Iron siderophore sensor protein & Iron_siderophore_sensor_\&_receptor_system \\
\hline PA4896 & & 3.14 & FUR & probable sigma-70 factor, ECF subfamily & Iron_siderophore_sensor_\&_receptor_system \\
\hline PA1911 & femR & 3.55 & & sigma factor regulator, FemR & \\
\hline PA1912 & feml & 5.53 & & ECF sigma factor, Feml & \\
\hline
\end{tabular}

systems PA1911-1912, PA4895-4896, PA2467-2468, PA0471-0472, and toxA were overexpressed at $\mathrm{pH} 7.5$ compared to pH6.0. We initially assumed that the PstSPhoB signaling/acquisition, which is normally activated under low phosphate conditions, might be paradoxically activated under high phosphate conditions at $\mathrm{pH} 7.5$ if $P$. aeruginosa experienced relative phosphate limitation as a result of shift to a less soluble dibasic form. Lack of increased expression of PstS-PhoB in the analysis suggested however that both $\mathrm{H}_{2} \mathrm{PO}_{4}{ }^{-}$and $\mathrm{HPO}_{4}{ }^{2-}$ are able to bind PstS and suppress the $\mathrm{PHO}$ regulon. The expression of quorum sensing genes including MvfRPQS QS system was not increased at pH7.5 consistent with our previously published data demonstrating a regulatory role of phosphate on the MvfR-PQS signaling pathway beyond quorum sensing [9].

While pyoverdin production is considered to be a quorum sensing related exoproduct of $P$. aeruginosa [19], our microarray results suggest that $\mathrm{pH}$ dependent expression of pyoverdin-related genes is not related to quorum sensing. To verify this, we dynamically measured $P$. aeruginosa PAO1 pyoverdin production during growth in liquid NGM media containing $25 \mathrm{mM}$ [Pi] at $\mathrm{pH} 7.5$ versus pH6.0. Results demonstrated that pyoverdin production was developed at $3 \mathrm{hrs}$ of growth (Figure 3A) at $25 \mathrm{mM} \mathrm{Pi}, \mathrm{pH} \mathrm{7.5}$, and was partially suppressed by the addition of $100 \mu \mathrm{M} \mathrm{Fe}^{3+}$. Most notably, suppression of pyoverdin production at [Pi] 25 $\mathrm{mM}, \mathrm{pH} 6.0$ was significantly higher compared to that provided by iron supplementation at [Pi] $25 \mathrm{mM} \mathrm{pH}$ 7.5. The concentration of iron in both liquid media NGM Pi25 mM, pH 6.0 and NGM Pi25 mM, pH 7.5 was measured and found to be very low $(<0.1 \mu \mathrm{g} / \mathrm{ml}$ $(<1.78 \mu \mathrm{M}))$. Given that the concentration of iron needed to partially attenuate pyoverdin production in NGM Pi25 mM, pH 7.5 is as high as $100 \mu \mathrm{M}$ (Figure $3 \mathrm{~A}$ ), we are confident that the $\mathrm{pH}$, not the extracellular iron concentration, was a major factor leading to the triggering of pyoverdin production under conditions of similar extracellular iron concentration. Since iron binding to pyoverdin quenches its fluorescence, the pyoverdin production in these experiments was measured in supernatants by absorbance at $405 \mathrm{~nm}$ as previously described [17], and measurements were normalized to initial cell density. Results demonstrated that the expression of pyoverdin can be prevented without providing iron by maintaining local phosphate abundance at $\mathrm{pH}$ 6.0. 


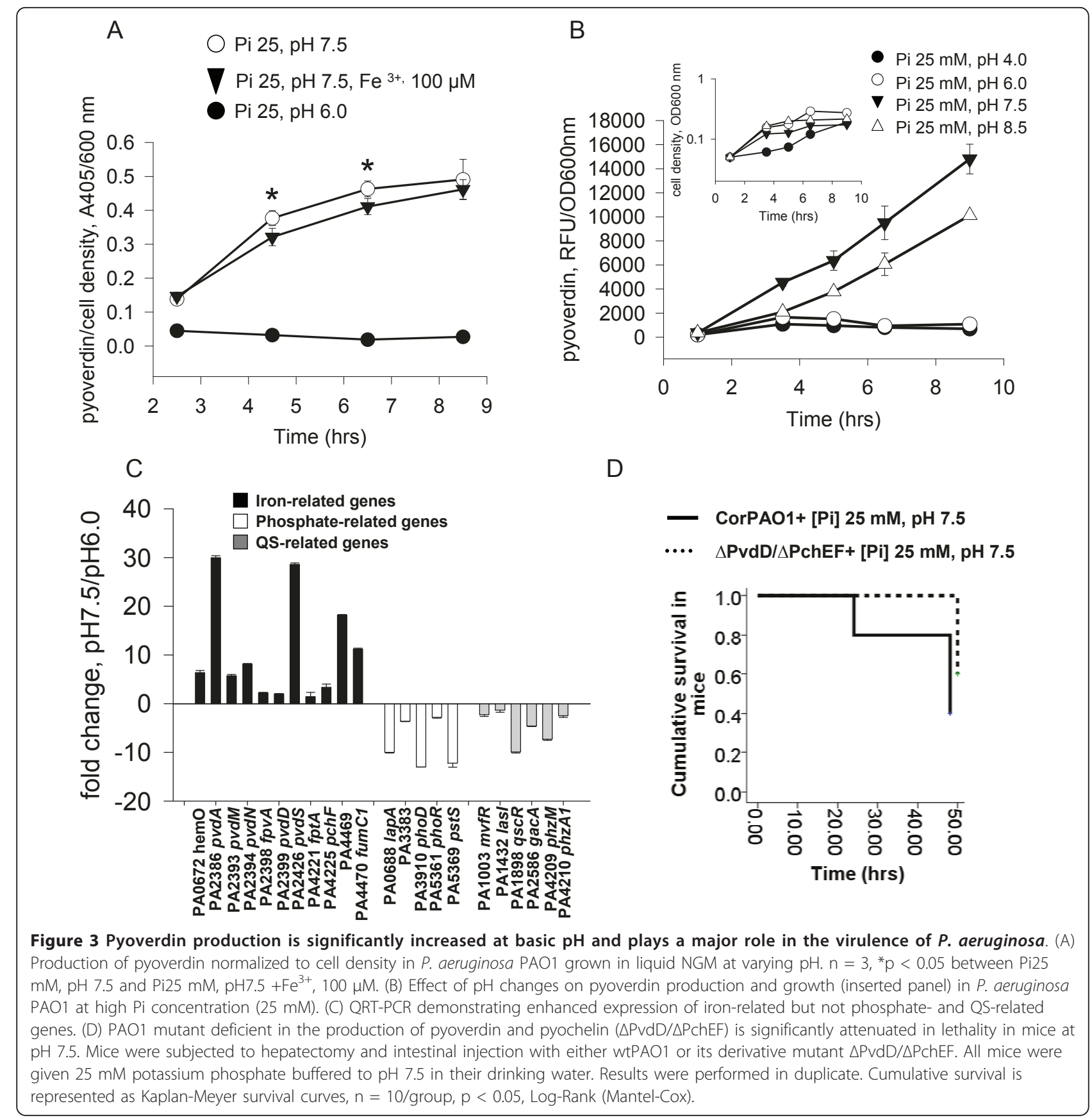

The effect of $\mathrm{pH}$ on pyoverdin production measured by fluorescence as previously described [9] was verified in the range of 4.0 to 8.5 (Figure 3B). Results demonstrated that the pyoverdin production is similar between pH4.0 and 6.0 (low level of pyoverdin), and between pH7.5 and 8.5 (high level of pyoverdin). We noticed however that the growth of $P$. aeruginosa at $\mathrm{pH} 4.0$ was greatly delayed up to 4 hrs (Figure $3 \mathrm{~B}$, inserted panel). At this point, the $\mathrm{pH}$ of bacterial culture changed on its own from 4.0 to 5.5 and further changed to $\mathrm{pH} \sim 6.0$ at
$9 \mathrm{hrs}$. Bacteria significantly increased their growth rate at 9 hours. Alternatively, bacteria grew very well at $\mathrm{pH}$ 8.5 , produced pyoverdin, and there was no change from the initial $\mathrm{pH}$. This finding supports our hypothesis that $P$. aeruginosa can regulate its environmental $\mathrm{pH}$ to facilitate its colonization.

Next, we measured the expression of QS- and ironrelated genes by qRT-PCR in $P$. aeruginosa $\mathrm{PAO} 1$ grown for 9 hrs in liquid NGM media at $\mathrm{pH} 7.5$ versus 6.0. Gene expression was normalized to tpiA (PA4748) 
expression and then fold change was determined using expression of PAO1 measured in NGM at pH 6.0 as $100 \%$. Results demonstrated increased expression of iron related genes and decreased expression of both quorum sensing and low phosphate- related genes at $\mathrm{pH} 7.5$ versus 6.0 (Figure $3 \mathrm{C}$ ). These data may confirm that $\mathrm{pH}$ mediated expression of iron- regulated genes is not dependent on quorum sensing. However, we found significant down-regulation (10 fold) of the $q s c R$ gene encoding LuxR-type “orphan” receptor QscR, a potent QS repressor [20]. As down- regulation of $q s c R$ may modulate LasRI activity at the same level of lasR expression [21-23], we cannot completely exclude the role of quorum sensing in pyoverdin regulation. QscR shares affinity for lactone QS molecules with LasR and can form inactive heterodimers with LasR and RhlR monomers to negatively regulate QS. Therefore attenuation of QscR production could lead to LasRI-mediated expression of pyoverdin-related genes. Results from our microarray analysis performed on high cell density cells demonstrate that $q s c R$ was down-regulated (-1.55) while lasR (1.6 fold) was upregulated (GEO database, accession number GSE29789). Such subtle changes in the expression of transcriptional regulators LasR and QscR may have profound downstream effects and therefore we cannot reject or confirm a regulatory role of QS in pyoverdin production at $\mathrm{pH}$ 7.5.

Finally to confirm the critical role of siderophores on $P$. aeruginosa lethality induced at $\mathrm{pH} 7.5$, we performed reiterative experiments using the double mutant $\triangle \mathrm{PvdD} \triangle \mathrm{PchEF}$ in mice. Intestinal inoculation with $\triangle \mathrm{PvdD} \triangle \mathrm{PchEF}$ resulted in attenuated lethality in mice exposed to surgical injury suggesting that iron acquisition factors (i.e pyoverdin and pyochelin) play an important role in $P$. aeruginosa mortality when mice are orally supplemented with phosphate (Pi $25 \mathrm{mM}$ ) at $\mathrm{pH} 7.5$ (Figure 3D).

\section{$P$. aeruginosa tends to alkalize medium at $\mathrm{pH} 6.0$}

Among the 126 genes that were up- regulated at $\mathrm{pH}$ 6.0, many appear to be associated with various cellular processes leading to media alkalization (Table 2). As case in point, expression of all genes of the arginine deiminase (ADI) pathway was enhanced $2.2-4.3$ fold at $\mathrm{pH}$ 6.0. The ADI pathway has been well established as a counteracting agent in acidic environments such as those encountered by various pathogens [24]. This pathway is unique in that it allows regeneration of ATP from ADP without generating reduced $\mathrm{NAD}(\mathrm{P})$ and without medium acidification due to the fact that most of its fermentation end-products are gaseous. Furthermore, ammonia production as a result of activation of this pathway directly alkalinizes the medium. The 2.1 - 3.5-fold increase in the expression of the spermidine export protein mdtJI homolog (PA1541 - PA1540) might also contribute to medium alkalization since production and excretion of polyamines has been shown in E. coli to contribute to an increase in the $\mathrm{pH}$ of the extracellular medium $[25,26]$. Multiple genes of the denitrification chain were upregulated at pH 6.0 as well, including those encoding the 4 core enzymatic complexes (nitrate reductase NAR, nitrite reductase NIR, nitric oxide reductase $\mathrm{NOR}$, and nitrous oxide reductase $\mathrm{N}_{2} \mathrm{OR}$ ), as well as supporting components, such as protoheme and heme $\mathrm{d} 1$ biosynthetic genes. This observation is in agreement with the computation based prediction that microbial assimilation of 1 mole nitrate or nitrite results in increase of alkalinity by 1 mole [27]. These results may be unexpected if one considers nitrate respiration and arginine fermentation to be strictly anaerobic processes. However, it has been well established that $P$. aeruginosa is capable of performing denitrification at relatively high dissolved oxygen levels [28-30]. The physiological role for aerobic denitrification has not yet been fully elucidated. From a purely energetic standpoint, the advantage of co-respiration using both oxygen and nitrate is not obvious, since energetically denitrification is less efficient than aerobic respiratory pathways. However, this apparent paradox has been addressed in different bacteria and additional physiological roles have been suggested for various denitrification enzymes [31]. Our own analysis of global gene expression in P. aeruginosa in this study points to role of aerobic denitrification as a response to media acidification assuming that aerobic denitrification might be essential for $P$. aeruginosa to maintain an optimum $\mathrm{pH}$ during infection of the gut. Similarly, the role of arginine deiminase system is far more complex than merely to support cellular survival under anaerobiosis. In fact, the major function of this system in a variety of lactic acid bacteria and Streptococcal species has been shown to protect organisms against acid damage [24,32]. For $P$. aeruginosa this role has not been previously demonstrated and therefore is novel. Finally we observed attenuated expression of multiple stress-related and resistance-related genes at $\mathrm{pH}$ 7.5. Taken together these findings suggest that $\mathrm{pH} 7.5$ is more physiologic for $P$. aeruginosa and that $P$. aeruginosa may regulate its environmental $\mathrm{pH}$ to facilitate its colonization and/or invasion.

\section{Comparative analysis of iron-related subsystems during phosphate limitation and a pH shift from 6.0 to 7.5 reveals the significant protective effect of phosphate supplementation}

We have previously shown that phosphate limitation induces three global virulence subsystems in P. aeruginosa PAO1 that include 1.) phosphate signaling/acquisition, 2.) MvfR-PQS of the core quorum sensing pathway 
Table 2 P. aeruginosa genes with decreased expression at pH 7.5 vs pH 6.0

\begin{tabular}{|c|c|c|c|c|}
\hline PA ID & $\begin{array}{l}\text { Gene } \\
\text { name }\end{array}$ & $\begin{array}{l}\text { Fold expression } \mathrm{pH} 7.5 \\
\text { vs } \mathrm{pH} 6.0\end{array}$ & Function & Subsystem \\
\hline PA5170 & $\operatorname{arcD}$ & -1.91 & Arginine/ornithine antiporter ArcD & Arginine deiminase pathway \\
\hline PA5171 & $\operatorname{arcA}$ & -4.3 & Arginine deiminase (EC 3.5.3.6) & Arginine deiminase pathway \\
\hline PA5172 & $\operatorname{arcB}$ & -2.82 & Ornithine carbamoyltransferase (EC 2.1.3.3) & Arginine deiminase pathway \\
\hline PA5173 & $\operatorname{arcC}$ & -2.13 & Carbamate kinase (EC 2.7.2.2) & Arginine deiminase pathway \\
\hline PA0530 & & -2.49 & Acetylornithine aminotransferase (EC 2.6.1.11) & Arginine_Biosynthesis_extended \\
\hline PA3865 & & -2.74 & $\begin{array}{l}\text { Arginine/ornithine } A B C \text { transporter, periplasmic arginine/ } \\
\text { ornithine binding protein }\end{array}$ & Arginine deiminase pathway \\
\hline PA1540 & & -2.14 & Spermidine export protein mdtl & Small_Multidrug_Resistance \\
\hline PA1541 & & -3.44 & Spermidine export protein mdtJ & Small_Multidrug_Resistance \\
\hline PA0509 & nirN & -3.39 & Nitrite reductase associated c-type cytochorome NirN & Dissimilatory_nitrite_reductase \\
\hline PA0510 & & -4.39 & Uroporphyrinogen-III methyltransferase (EC 2.1.1.107) & Dissimilatory_nitrite_reductase \\
\hline PA0511 & nirJ & -5.67 & Heme d1 biosynthesis protein NirJ & Dissimilatory_nitrite_reductase \\
\hline PA0512 & & -1.84 & Heme d1 biosynthesis protein $\mathrm{NirH}$ & Dissimilatory_nitrite_reductase \\
\hline PA0513 & & -1.76 & Heme d1 biosynthesis protein NirG & Dissimilatory_nitrite_reductase \\
\hline PA0514 & nirL & -2.32 & Heme d1 biosynthesis protein NirL & Dissimilatory_nitrite_reductase \\
\hline PA0515 & & -7.33 & Heme d1 biosynthesis protein NirD & Dissimilatory_nitrite_reductase \\
\hline PA0516 & nirF & -2.59 & Heme d1 biosynthesis protein NirF & Dissimilatory_nitrite_reductase \\
\hline PA0517 & nirC & -7.03 & Cytochrome c55X precursor NirC & Dissimilatory_nitrite_reductase \\
\hline PA0518 & nirM & -10.01 & Cytochrome c551 NirM & Dissimilatory_nitrite_reductase \\
\hline PA0519 & nirs & -8.9 & Cytochrome cd1 nitrite reductase (EC:1.7.2.1) & Denitrification \\
\hline PA0520 & nirQ & -2.02 & Nitric oxide reductase activation protein NorQ & Denitrification \\
\hline PA0521 & & -1.91 & Nitric oxide reductase activation protein NorE & Denitrification \\
\hline PA0523 & norC & -8.51 & Nitric-oxide reductase subunit C (EC 1.7.99.7) & Denitrification \\
\hline PA0524 & norB & -9.78 & Nitric-oxide reductase subunit B (EC 1.7.99.7) & Denitrification \\
\hline PA0525 & & -3.39 & Nitric oxide reductase activation protein NorD & Denitrification \\
\hline PA1172 & napC & -1.51 & Cytochrome c-type protein NapC & Nitrate_and_nitrite_ammonification \\
\hline PA1173 & napB & -2.01 & Nitrate reductase cytochrome c550-type subunit & Nitrate_and_nitrite_ammonification \\
\hline PA1174 & napA & -2.01 & Periplasmic nitrate reductase precursor (EC 1.7.99.4) & Nitrate_and_nitrite_ammonification \\
\hline PA2662 & & -1.90 & NnrS protein involved in response to $\mathrm{NO}$ & Denitrification \\
\hline PA3391 & nosR & -2.17 & Nitrous oxide reductase maturation protein NosR & Denitrification \\
\hline PA3392 & nosZ & -3.16 & Nitrous-oxide reductase (EC 1.7.99.6) & Denitrification \\
\hline PA3393 & nosD & -1.40 & Nitrous oxide reductase maturation protein NosD & Denitrification \\
\hline PA2826 & & -5.48 & Glutathione peroxidase family protein & Stress response \\
\hline PA2850 & & -2.28 & Organic hydroperoxide resistance protein & Stress response \\
\hline PA3017 & & -1.56 & $\begin{array}{l}\text { Universal stress protein UspA and related nucleotide- } \\
\text { binding proteins }\end{array}$ & Stress response \\
\hline PA3309 & & -3.47 & $\begin{array}{l}\text { Universal stress protein UspA and related nucleotide- } \\
\text { binding proteins }\end{array}$ & Stress response \\
\hline PA4352 & & -7.28 & $\begin{array}{l}\text { Universal stress protein UspA and related nucleotide- } \\
\text { binding proteins }\end{array}$ & Stress response \\
\hline PA5027 & & -4.50 & $\begin{array}{l}\text { Universal stress protein UspA and related nucleotide- } \\
\text { binding proteins }\end{array}$ & Stress response \\
\hline PA4760 & dnaJ & -2.02 & Chaperone protein DnaJ & Stress response \\
\hline PA4761 & dnak & -2.41 & Chaperone protein DnaK & Stress response \\
\hline PA4762 & grpE & -2.70 & Heat shock protein GrpE & Stress response \\
\hline PA4587 & $\mathrm{ccpR}$ & -12.82 & Cytochrome c551 peroxidase (EC 1.11.1.5) & Stress response \\
\hline PA4206 & & -3.50 & Probable Co/Zn/Cd efflux system membrane fusion protein & Resistance \\
\hline PA4207 & & -3.52 & $\begin{array}{l}\text { RND multidrug efflux transporter; Acriflavin resistance } \\
\text { protein }\end{array}$ & Resistance \\
\hline$\overline{\text { PA4208 }}$ & & -3.52 & Probable outer membrane efflux protein precursor & Resistance \\
\hline
\end{tabular}


and downstream regulated genes such as those involved in the biosynthesis of pyocyanin, and 3.) pyoverdinrelated genes (Figure 4A, A') (Microarray data for phosphate limitation are deposited in GEO database, GEO accession number GSE30967). The upregulation of pyoverdin by phosphate limitation was surprising given that the expression of pyoverdin genes is regulated by the transcriptional regulator PvdS that by itself is part of the FUR regulon, and as such the expression of PvdS and its regulated genes strongly depends on iron concentration. One would assume that there is going to be more iron available at lower concentrations of phosphate since phosphate causes precipitation of iron, thereby decreasing its effective concentration. Indeed, the absence of activation of FUR-regulated genes (normally suppressed at high concentration of iron) suggested that iron was available for $P$. aeruginosa (Figure 4A) indicating that the response of $P$. aeruginosa at differing levels of $\mathrm{Pi}$ is not simply a matter of the interaction of iron and phosphate, but rather involves more complex yetto- be elucidated mechanisms. Alternatively, the expression of pyoverdin genes and FUR regulon in high phosphate media at $\mathrm{pH} 7.5$ (Figure 4B) demonstrated that $P$. aeruginosa was exposed to iron limiting conditions. Comparison of the signature of iron related genes during $\mathrm{pH}$ shift to 7.5 to that induced by iron limitation as reported by Ochsner et. al. [33] (Figure 4C) confirmed that $P$. aeruginosa experiences iron limitation at $\mathrm{pH}$ 7.5. Importantly, providing phosphate at $\mathrm{pH} 6.0$ suppressed the expression of iron-related genes indicating a significant protective effect of phosphate supplementation at pH6.0.

\section{Discussion}

Results from the present study build on our previous work to understand how local cues within the intestinal tract reservoir affect the virulence of colonizing pathogens that are capable of causing lethal gut- derived sepsis. Microbes that colonize the gut following extreme medical interventions such as major organ transplantation are under an unprecedented level of pressure to adapt to an highly abnormal environment in which $\mathrm{pH}$ is shifted, nutrient resources are limited, and the normal microbial flora is dramatically altered by the combined effects of extreme physiologic stress and antibiotic treatment. In this regard, the human opportunistic pathogen $P$. aeruginosa has been shown to rapidly colonize such patients and be a major primary source of infection and sepsis [34]. In many cases of severe sepsis the primary pathogen remains unidentified. In this regard, intestinal $P$. aeruginosa is particularly suited to use the intestinal tract as a privileged site with its unique ability to survive, persist, and mount a toxic offensive without extraintestinal dissemination (gut-derived sepsis) [35]. The emergence of pan-resistant strains of $P$. aeruginosa that often colonize the gut of the most critically ill patients begs the development of a non- antibiotic based approach that can suppress virulence activation of $P$. aeruginosa through the course of surgery or immunosuppression as a containment rather than elimination strategy. To achieve this, a more complete understanding of the physico-chemical cues that characterize colonization sites of intestinal pathogens in critically ill patients is needed.

Our previous work suggests that a major environmental cue that shifts $P$. aeruginosa to express a lethal phenotype within the intestinal tract of surgically injured mice is the mucosal phosphate. During surgical injury, phosphate becomes depleted within the intestinal mucus and signals $P$. aeruginosa to express a lethal phenotype via pathways that triangulate three global virulence subsystems: phosphate signaling and acquisition, MvfR-PQS of quorum sensing, and pyoverdin production [9]. Importantly, maintenance of phosphate abundance/sufficiency via oral supplementation prevents activation of these pathways and attenuates mortality in mice and $C$. elegans. Results from the present study emphasize the importance of $\mathrm{pH}$ on the ability of phosphate to protect mice and C. elegans from the lethal effect of intestinal $P$. aeruginosa. This is particularly important given the observation that $\mathrm{pH}$ in the distal intestinal tract is increased in response to surgical injury. We focused on $\mathrm{pH}$ changes in the proximal colon (cecum) as it is the densest site of microbial colonization and the site of greatest immune activation in response to intestinal pathogens [36-40]. In addition, various reports confirm that experimental injury or human critical illness results in a similar shift in distal intestinal $\mathrm{pH}$ from a normal value of 6 to $>7$ in both animals and humans $[1,11,16]$. Therefore the transcriptional response of $P$. aeruginosa PAO1 when the $\mathrm{pH}$ is shifted from 6.0 to 7.5 may have particular relevance in vivo.

Microarray and qRT-PCR analysis demonstrated the upregulation of all iron-regulated genes including pyoverdin-related ones at $\mathrm{pH} 7.5$ but did not demonstrate an increase in the expression of the quorum sensing system suggesting that iron acquisition is the main virulence feature of $P$. aeruginosa under these conditions. Interestingly, the expression pattern of other genes at $\mathrm{pH} 6.0$ compared to 7.5 demonstrated the increased expression of multiple genes associated with cellular processes involved in media alkalization including expression of denitrification genes in P. aeruginosa which, to our knowledge, has not been previously reported. Finally we observed attenuated expression of multiple stress-related and resistancerelated genes at $\mathrm{pH} 7.5$. Taken together these findings suggest that pH7.5 is more physiologic for $P$. 


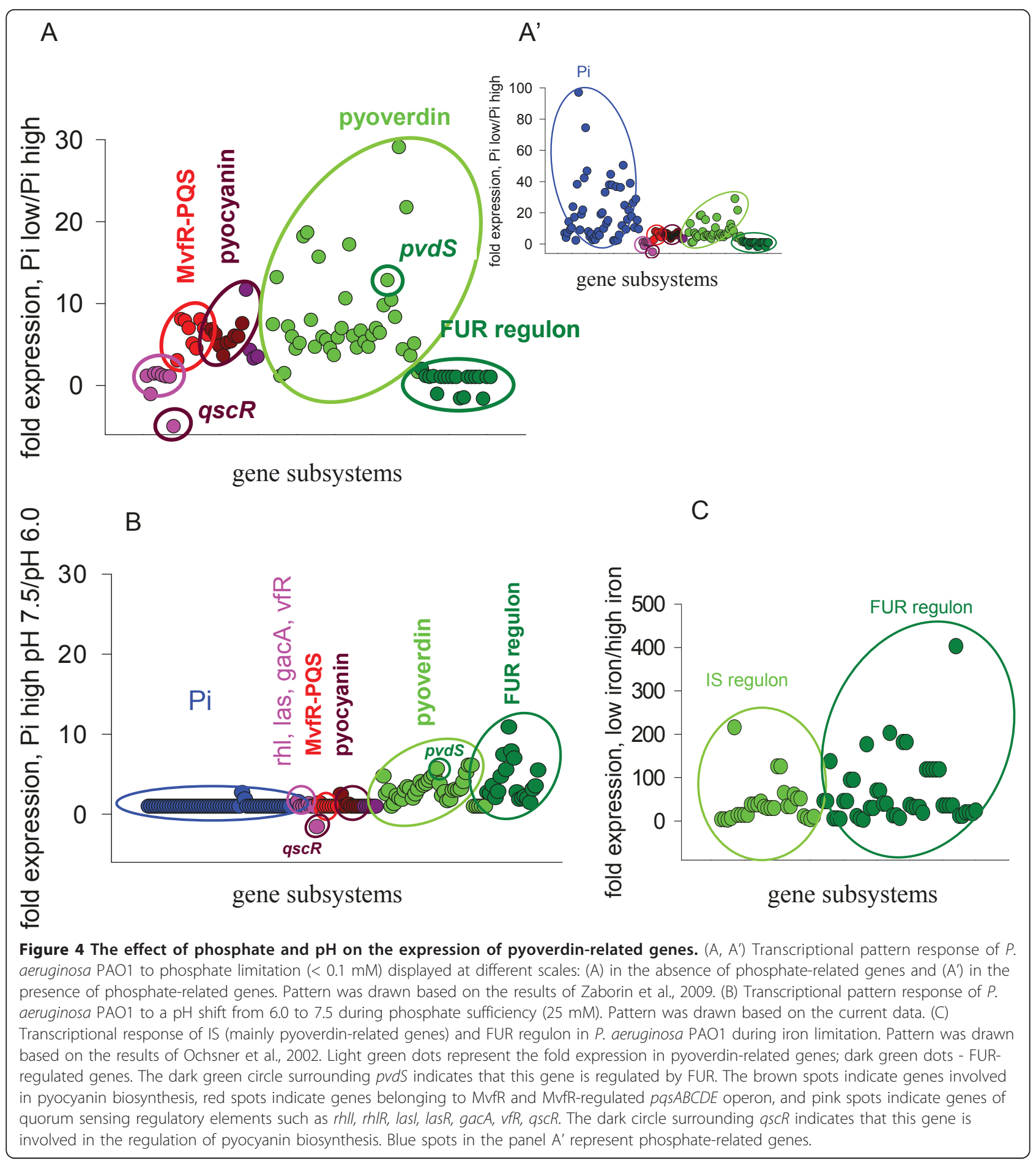

aeruginosa and that $P$. aeruginosa may regulate its environmental $\mathrm{pH}$ to facilitate its colonization and/or invasion being well equipped with multiple siderophores. Thus, these data provide one more example that demonstrates the connectedness of the metabolic and virulence response in $P$. aeruginosa. As a result of exposure to physiologic cues present in post-surgical patients, intestinal $P$. aeruginosa may be activated to alkalinize its local microenvironment which itself will lead to less iron availability and hence enhanced virulence. Thus a preventative strategy to maintain the intestinal $\mathrm{pH}$ at a more suitable level that suppresses virulence activation in problematic colonizing pathogens such as $P$. aeruginosa should be considered. 
Data from the present study suggest that suppression of siderophore-related virulence expression in $P$. aeruginosa can be achieved without the need to provide iron by creating conditions of local phosphate sufficiency at pH6.0. This finding may be particularly important as provision of exogenous iron has been shown to have untoward effects when administered to critically ill and septic patients [41-43]. Iron administration has been shown to impair neutrophils function, increase the incidence of infections, and cause hemodynamic compromise in critically ill patients $[41,44-47]$. Data from the present study suggest that maintenance of phosphate and $\mathrm{pH}$ at appropriate physiologic levels prevents virulence activation in a site specific manner and as such, is an example of a non- antibiotic, anti-virulence based strategy to suppress the lethality of highly virulent pathogens such as $P$. aeruginosa. Given that phosphate, $\mathrm{pH}$, and iron are near universal cues that suppress/activate the virulence of a broad range of microorganisms relevant to serious gut origin infection and sepsis in critically ill patients, a more complete understanding of how these elements can be controlled in a site specific manner through the course of extreme physiologic stress could led to novel anti-infective therapies in at risk patients.

\section{Conclusion}

The GI tract expresses a highly variable $\mathrm{pH}$ that is region dependent and is affected by various physiologic conditions such as ischemia and the use of acid suppressing agents and other drugs employed during the treatment of critically ill patients. A shift in $\mathrm{pH}$ to $\sim 7.5$ in the intestinal mucus during physiological stress can lead to activation of multiple siderophore-related genes that directly impact microbial virulence. We show for the first time that suppression of siderophore-related virulence expression in $P$. aeruginosa can be achieved without providing iron by creating conditions of local phosphate sufficiency at $\mathrm{pH}$ 6.0. These findings may have significant therapeutic implications given that there is reluctance to provide excess iron in the face of life threatening infection. Understanding the local cues that activate virulence of common pathogens that colonize the gut during critical illness may lead to new insight into their pathogenesis.

\section{Acknowledgements}

We thank Irina Morozova for her technical assistance, Pierre Cornelis for $\triangle \mathrm{PvdD} / \triangle \mathrm{P} c h E F$ double mutant, and Michael Vasil for permission to interpret and present his data (Ochsner et al., 2002) in Figure 4 for discussion purposes. We thank Jaejung Kim, Siming Shou, and Ashwin Vishnuvardhana, the University of Chicago Core Functional Genomics Facility for processing and statistical analysis of microarray data.

This study was funded by NIH RO1 GM062344-11 (JA).

\section{Author details}

'Department of Surgery, the University of Chicago, 5841 S. Maryland, Chicago, IL 60637, USA. 'Fellowship for Interpretation of Genomes, 15 w155 81st, Burr Ridge, IL 60527, USA. ${ }^{3}$ Department of Surgery, St. Joseph's Hospital and Medical Center, 350 West Thomas Rd, Phoenix, AZ 85013, USA

\section{Authors' contributions}

$\mathrm{KR}$ carried out measurements of intestinal mucosal $\mathrm{pH}$, ran mice experiments, and measured iron concentration; AZ carried out C. elegans experiments, RNA isolation and preparation for microarray analysis, and performed pyoverdin assays; HF conceived of the study, measured intestinal mucus $\mathrm{pH}$, and pyoverdin production; VP performed RT-PCR analysis; W ran mice experiments; SG participated in the reconstruction of the microarray data to reveal main affected subsystems; DL conceived of the study, and participated in its design; OZ conceived of the study, participated in its design and coordination, performed microarray analysis, and wrote the manuscript; JA coordinated the study, participated in the design, and wrote the manuscript. All authors read and approved the final manuscript.

Received: 24 May 2011 Accepted: 26 September 2011

Published: 26 September 2011

\section{References}

1. Shimizu K, Ogura H, Goto M, Asahara T, Nomoto K, Morotomi M, Yoshiya K, Matsushima A, Sumi Y, Kuwagata Y, et al: Altered gut flora and environment in patients with severe SIRS. J Trauma 2006, 60(1):126-133.

2. Hayakawa M, Asahara T, Henzan N, Murakami H, Yamamoto H, Mukai N, Minami Y, Sugano M, Kubota N, Uegaki S, et al: Dramatic Changes of the Gut Flora Immediately After Severe and Sudden Insults. Dig Dis Sci 2011, 58(8):2361-2365

3. Vincent JL, Rello J, Marshall J, Silva E, Anzueto A, Martin CD, Moreno R, Lipman J, Gomersall C, Sakr Y, et al: International study of the prevalence and outcomes of infection in intensive care units. Jama 2009, 302(21):2323-2329.

4. Okuda J, Hayashi N, Okamoto M, Sawada S, Minagawa S, Yano Y, Gotoh N: Translocation of Pseudomonas aeruginosa from the intestinal tract is mediated by the binding of ExoS to an $\mathrm{Na}$, K-ATPase regulator, FXYD3. Infect Immun 78(11):4511-4522.

5. Wu L, Holbrook C, Zaborina O, Ploplys E, Rocha F, Pelham D, Chang E, Musch M, Alverdy J: Pseudomonas aeruginosa expresses a lethal virulence determinant, the PA-I lectin/adhesin, in the intestinal tract of a stressed host: the role of epithelia cell contact and molecules of the Quorum Sensing Signaling System. Ann Surg 2003, 238(5):754-764.

6. Zaborina O, Kohler JE, Wang Y, Bethel C, Shevchenko O, Wu L, Turner JR, Alverdy JC: Identification of multi-drug resistant Pseudomonas aeruginosa clinical isolates that are highly disruptive to the intestinal epithelial barrier. Ann Clin Microbiol Antimicrob 2006, 5:14.

7. Zaborina O, Holbrook C, Chen Y, Long J, Zaborin A, Morozova I, Fernandez H, Wang Y, Turner JR, Alverdy JC: Structure-function aspects of PstS in multi-drug-resistant Pseudomonas aeruginosa. PLOS Pathog 2008, 4(2):e43.

8. Long J, Zaborina O, Holbrook C, Zaborin A, Alverdy J: Depletion of intestinal phosphate after operative injury activates the virulence of $\mathrm{P}$ aeruginosa causing lethal gut-derived sepsis. Surgery 2008, 144(2):189-197.

9. Zaborin A, Romanowski K, Gerdes S, Holbrook C, Lepine F, Long J, Poroyko V, Diggle SP, Wilke A, Righetti $K$, et al: Red death in Caenorhabditis elegans caused by Pseudomonas aeruginosa PAO1. Proc Natl Acad Sci USA 2009, 106(15):6327-6332.

10. Zaborina O, Zaborin A, Romanowski K, Babrowski T, Alverdy J: Host Stress and Virulence Expression in Intestinal Pathogens: Development of Therapeutic Strategies using Mice and C. elegans. Curr Pharm Des 2011, 17(13):1254-1260.

11. Nugent SG, Kumar D, Rampton DS, Evans DF: Intestinal luminal pH in inflammatory bowel disease: possible determinants and implications for therapy with aminosalicylates and other drugs. Gut 2001, 48(4):571-577.

12. Bown RL, Gibson JA, Sladen GE, Hicks B, Dawson AM: Effects of lactulose and other laxatives on ileal and colonic $\mathrm{pH}$ as measured by a radiotelemetry device. Gut 1974, 15(12):999-1004. 
13. Ewe K, Schwartz S, Petersen S, Press AG: Inflammation does not decrease intraluminal pH in chronic inflammatory bowel disease. Dig Dis Sci 1999, 44(7):1434-1439.

14. Press AG, Hauptmann IA, Hauptmann L, Fuchs B, Fuchs M, Ewe K, Ramadori G: Gastrointestinal pH profiles in patients with inflammatory bowel disease. Aliment Pharmacol Ther 1998, 12(7):673-678.

15. Evans DF, Pye G, Bramley R, Clark AG, Dyson TJ, Hardcastle JD: Measurement of gastrointestinal $\mathrm{pH}$ profiles in normal ambulant human subjects. Gut 1988, 29(8):1035-1041.

16. Alverdy J, Holbrook C, Rocha F, Seiden L, Wu RL, Musch M, Chang E, Ohman D, Suh S: Gut-derived sepsis occurs when the right pathogen with the right virulence genes meets the right host: evidence for in vivo virulence expression in Pseudomonas aeruginosa. Ann Surg 2000 232(4):480-489.

17. Wagner T, Soong G, Sokol S, Saiman L, Prince A: Effects of azithromycin on clinical isolates of Pseudomonas aeruginosa from cystic fibrosis patients. Chest 2005, 128(2):912-919.

18. Laughlin RS, Musch MW, Hollbrook CJ, Rocha FM, Chang EB, Alverdy JC: The key role of Pseudomonas aeruginosa PA-I lectin on experimental gut-derived sepsis. Ann Surg 2000, 232(1):133-142.

19. Stintzi A, Evans K, Meyer JM, Poole K: Quorum-sensing and siderophore biosynthesis in Pseudomonas aeruginosa: lasR/lasl mutants exhibit reduced pyoverdine biosynthesis. FEMS Microbiol Lett 1998, 166(2):341-345.

20. Fuqua C: The QscR quorum-sensing regulon of Pseudomonas aeruginosa: an orphan claims its identity. J Bacteriol 2006, 188(9):3169-3171.

21. Chugani SA, Whiteley M, Lee KM, D'Argenio D, Manoil C, Greenberg EP: QscR, a modulator of quorum-sensing signal synthesis and virulence in Pseudomonas aeruginosa. Proc Natl Acad Sci USA 2001, 98(5):2752-2757.

22. Lee JH, Lequette $Y$, Greenberg EP: Activity of purified QscR, a Pseudomonas aeruginosa orphan quorum-sensing transcription factor. Mol Microbiol 2006, 59(2):602-609

23. Ledgham F, Ventre I, Soscia C, Foglino M, Sturgis JN, Lazdunski A: Interactions of the quorum sensing regulator QscR: interaction with itself and the other regulators of Pseudomonas aeruginosa LasR and RhIR. Mol Microbiol 2003, 48(1):199-210.

24. Curran TM, Lieou J, Marquis RE: Arginine deiminase system and acid adaptation of oral streptococci. Appl Environ Microbiol 1995, 61(12):4494-4496.

25. Neely MN, Olson ER: Kinetics of expression of the Escherichia coli cad operon as a function of $\mathrm{pH}$ and lysine. J Bacteriol 1996, 178(18):5522-5528.

26. Soksawatmaekhin W, Kuraishi A, Sakata K, Kashiwagi K, Igarashi K: Excretion and uptake of cadaverine by $\mathrm{CadB}$ and its physiological functions in Escherichia coli. Mol Microbiol 2004, 51(5):1401-1412.

27. Wolf-Gladrow, Dieter A, Zeebe, Richard E, Klaas, Christine, Körtzinger, Arne and Dickson, Andrew G: Total alkalinity: The explicit conservative expression and its application to biogeochemical processes. Marine Chemistry 2007, 106(1-2):287-300.

28. Davies KJ, Lloyd D, Boddy L: The effect of oxygen on denitrification in Paracoccus denitrificans and Pseudomonas aeruginosa. J Gen Microbiol 1989, 135(9):2445-2451

29. Chen F, Xia Q, Ju LK: Aerobic denitrification of Pseudomonas aeruginosa monitored by online NAD(P)H fluorescence. Appl Environ Microbiol 2003, 69(11):6715-6722.

30. Williams HD, Zlosnik JE, Ryall B: Oxygen, cyanide and energy generation in the cystic fibrosis pathogen Pseudomonas aeruginosa. Adv Microb Physiol 2007, 52:1-71

31. Richardson DJ: Bacterial respiration: a flexible process for a changing environment. Microbiology 2000, 146(Pt 3):551-571.

32. Casiano-Colon A, Marquis RE: Role of the arginine deiminase system in protecting oral bacteria and an enzymatic basis for acid tolerance. Appl Environ Microbiol 1988, 54(6):1318-1324.

33. Ochsner UA, Wilderman PJ, Vasil Al, Vasil ML: GeneChip expression analysis of the iron starvation response in Pseudomonas aeruginosa: identification of novel pyoverdine biosynthesis genes. Mol Microbiol 2002, 45(5):1277-1287

34. Aliaga L, Mediavilla JD, Cobo F: A clinical index predicting mortality with Pseudomonas aeruginosa bacteraemia. J Med Microbiol 2002, 51(7):615-619.
35. Bertrand X, Thouverez M, Talon D, Boillot A, Capellier G, Floriot C, Helias JP: Endemicity, molecular diversity and colonisation routes of Pseudomonas aeruginosa in intensive care units. Intensive Care Med 2001, 27(8):1263-1268

36. Alverdy JC, Chang EB: The re-emerging role of the intestinal microflora in critical illness and inflammation: why the gut hypothesis of sepsis syndrome will not go away. J Leukoc Biol 2008, 83(3):461-466.

37. O'Hara AM, Shanahan F: The gut flora as a forgotten organ. EMBO Rep 2006, 7(7):688-693

38. Sekirov I, Finlay BB: The role of the intestinal microbiota in enteric infection. J Physiol 2009, 587(Pt 17):4159-4167.

39. Lupp C, Robertson ML, Wickham ME, Sekirov I, Champion OL, Gaynor EC, Finlay BB: Host-mediated inflammation disrupts the intestinal microbiota and promotes the overgrowth of Enterobacteriaceae. Cell Host Microbe 2007, 2(2):119-129.

40. Atarashi K, Tanoue T, Shima T, Imaoka A, Kuwahara T, Momose Y, Cheng G, Yamasaki S, Saito $T$, Ohba $Y$, et al: Induction of colonic regulatory $T$ cells by indigenous Clostridium species. Science 331(6015):337-341.

41. Piagnerelli M, Vincent $J$ : Role of iron in anaemic critically ill patients: it's time to investigate! Crit Care 2004, 8(5):306-307.

42. Bor-Kucukatay M, Yalcin O, Meiselman HJ, Baskurt OK: Erythropoietininduced rheological changes of rat erythrocytes. Br J Haematol 2000, 110(1):82-88

43. Casadevall N, Nataf J, Viron B, Kolta A, Kiladjian JJ, Martin-Dupont P, Michaud P, Papo T, Ugo V, Teyssandier I, et al: Pure red-cell aplasia and antierythropoietin antibodies in patients treated with recombinant erythropoietin. N Engl J Med 2002, 346(7):469-475.

44. Patruta SI, Horl WH: Iron and infection. Kidney Int Suppl 1999, 69:S125-130.

45. Sunder-Plassmann G, Patruta SI, Horl WH: Pathobiology of the role of iron in infection. Am J Kidney Dis 1999, 34(4 Suppl 2):S25-29.

46. Alexander J, Limaye AP, Ko CW, Bronner MP, Kowdley KV: Association of hepatic iron overload with invasive fungal infection in liver transplant recipients. Liver Transp/ 2006, 12(12):1799-1804.

47. Khan FA, Fisher MA, Khakoo RA: Association of hemochromatosis with infectious diseases: expanding spectrum. Int J Infect Dis 2007, 11(6):482-487.

\section{doi:10.1186/1471-2180-11-212}

Cite this article as: Romanowski et al: Prevention of siderophoremediated gut-derived sepsis due to $P$. aeruginosa can be achieved without iron provision by maintaining local phosphate abundance: role of $\mathrm{pH}$. BMC Microbiology 2011 11:212.

\section{Submit your next manuscript to BioMed Central and take full advantage of:}

- Convenient online submission

- Thorough peer review

- No space constraints or color figure charges

- Immediate publication on acceptance

- Inclusion in PubMed, CAS, Scopus and Google Scholar

- Research which is freely available for redistribution

Submit your manuscript at www.biomedcentral.com/submit
C Biomed Central 